\title{
No commercial break for combination treatment
}

The US Patent and Trademark Office's (PTO)refusal to extend a drug patent to Arnold Partnership for the combination of a cough suppressant and a pain reliever was upheld by the Federal court, who agreed that the applicant had failed to satisfy the "first commercial marketing" requirement of the 35 U.S.C. statute.

Arnold Partnership holds a patent (US 4,587,252) on a pharmaceutical composition consisting of the cough suppressant hydrocodone and the pain reliever ibuprofen. Marketed as Vicoprofen, it was the first commercial drug approved by the FDA that combined the two compounds, although both compounds had been marketed previously as separate drugs.

Arnold's application to extend the ' 252 patent term beyond its 18 December 2004 expiration date was refused by the PTO because of failure to satisfy a section of the statute requiring that permission for commercial marketing sought after the regulatory review period is the first permitted commercial marketing or use of the product under which such regulatory review period occurred. According to the PTO, the previous and separate market approvals for hydrocodone bitartrate and ibuprofen prevented Vicoprofen from satisfying the first commercial marketing requirement, even though those two drugs had never been approved in combination.
Arnold argued that the term 'product' means the combination of the active ingredients hydrocodone bitartrate and ibuprofen, which had not previously been marketed at the time that the application was filed. The plaintiff argued that reference to the 'active ingredient' shows that Congress intended a 'drug product' to have only a single active ingredient. Therefore in a drug composed of several active ingredients, 'the active ingredient' means the combination of constituent active ingredients. According to the PTO, Arnold's interpretation would render meaningless the portion of the statute that defines 'drug product' to include "any salt or ester of the active ingredient", given that it is not chemically possible to have a "salt or ester" of a combination of active ingredients.

The Federal Court agreed and also dismissed the plaintiff's suggestion that patent extension could be granted to an active ingredient that, as a single entity, had never received FDA approval. The court maintained that the PTO's practice is also consistent with the statute's failure to allow extensions for new uses or dosage forms of previously approved drugs, and shows Congress' intent that only new, pioneer chemical entities should have their lives legislatively renewed.

Arnold Partnership versus Dudas 03-1339 (24 March 2004) Rader, J.: http://www.fedcir.gov/opinions/03-1339.doc

\section{Patent office decision over restriction requirement scrutinized}

Bristol-Myers Squibb's district court victory defending one of its patents was overturned by the Federal Circuit, due to invalidity for double patenting. The applications and patents at issue (US Patents 4,657,927 and 4,140,707) cover platinum compounds for treating tumours and methods for their use. When generics manufacturer Pharmachemie filed an Abbreviated New Drug Application seeking US FDA approval to market the anticancer drug carboplatin, covered by the ' 927 patent, BMS sued them for infringement. Pharmachemie claimed that the' 927 patent was invalid because of obviousness-type double patenting over the '707 patent, which expired in 1998.

The double-patenting issue in this case hinges on whether BMS is entitled to invoke section 121 of the Patent Act, 35 U.S.C., as a defence against the claim of double patenting. That issue in turn depends on an interpretation of the prosecution history of the ' 707 and ' 927 patents, which is very complicated: there were four applications and six restriction requirements issued during the fifteen years from the original application filing to the granting of the ' 927 patent. A restriction requirement occurs when an examiner concludes that a patent application claims two or more independent and distinct inventions. The requirement obliges the applicant to elect to pursue one group of claims in the application in which the requirement is made. The non-elected claims can be pursued by a divisional application - a later application for an independent or distinct invention taken out of a pending application and disclosing and claiming only subject matter disclosed in the earlier or parent application

The federal court overturned the district court decision, because the later-issued patent arose from another restriction requirement that was not consonant with the original restriction requirement from a parent application. Dissenting from the majority in the federal court decision, Judge Newman argued that the PTO's restriction practice was not reviewable and that the court had created a new ground of patent invalidity.
Bristol-Myers Squibb Co. versus Pharmachemie B. V. 03-1077 (17 March 2004) Bryson, J.: http://www.fedcir.gov/opinions/03-1077.doc

\section{Chiron claims against Genentech patent dismissed again}

After a number of rounds through the courts, a Federal Appeals court upheld an earlier District Court judgement in favour of Genentech that all claims asserted by Chiron for alleged infringement of its patent for trastuzumab (Herceptin) are invalid.

In 2002, Chiron sued Genentech for patent infringement, alleging that it had invented a crucial technology (US Patent $6,054,561)$ used in creating the metastaticbreast-cancer blockbuster drug trastuzumab. The company claimed that it was entitled to as much as $30 \%$ of drug sales; however, a federal jury unanimously decided that Chiron had no claim to share any profits from trastuzumab, deciding that the US Patent and Trademark Office had improperly granted Chiron's patent. 